\title{
A PESTI SERFŐZÉSTŐL A SÖRGYÁRTÁSIG
}

\author{
BUDAPEST FÖVÁROS LEVÉLTÁRÁNAK KIÁLLÍTÁSA \\ IPARI ÉPÍTÉSZET TÖRTÉNETE TÉMAKÖRBEN \\ (2017. 06. 09. - 2017. 10. 31.)
}

\author{
MARTIN PILSITZ \\ PhD, építészmérnök. BME Építésztörténeti és Müemléki Tanszék, \\ 1111 Budapest, Müegyetem rkp. 3. K II. 82. Tel.: (+36-20) 454-8261. E-mail: pilsitz.martin@gmail.com
}

\begin{abstract}
A kiállítás a budapesti történeti ipari építészet egyik fontos szeletét mutatja be. A rendezők nem titkolt célja, hogy megváltoztassák és kiegészítsék az ipari építészettel kapcsolatban elterjedt általános sztereotípiákat. A kiállított gazdag forrásanyag a korai budapesti sörfőzdék példáján keresztül áttekinthetővé teszi azt a hatalmas fejlődést, amelyen az épülettípus az 1815. év és az első világháború közötti időszakban alaprajzi, szerkezeti és méretbeli szempontból, valamint a környezö urbánus környezetre való hatása tekintetében átesett, továbbá felcsillantja az épületek e hatások következtében kialakult összetéveszthetetlenül sajátos esztétikáját is. Erős egyszerüsítés lenne ezt a jelenséget kizárólag a „funkcionális építészet" túlságosan is átfogó fogalmával magyarázni. A kiállítás ezzel a fogalmi redukcióval szakítva mutatja be a korai budapesti gyárépületek sokoldalúan gazdag építészetét. Ezek az épületek ugyanis éppen úgy alkalmasak az identitáshordozói szerepkörre, mint a templomok vagy a paloták, és ezt az állítást a Budapest Főváros Levéltárában őrzött gazdag történeti forrásanyag is jelentősen alátámasztja.
\end{abstract}

Kulcsszavak: Dreher, Hild József, budapesti történeti sörfözdék, Krauß János, Mayerffy, Proberger, Tüköry, Zofahl Lörinc

\section{A KORAI IPARI ÉPÜLETEK SZERVES RÉSZEI BUDAPEST ÉPÍTÉSZETTÖRTÉNETÉNEK}

Budapest ipar- és technikatörténetét nagyon sokan feldolgozták. Az eredményeket gazdag szakirodalmi publikációkban dokumentálták, és a téma több kiállítás keretében is bemutatásra került. Ugyanez mondható el számos budapesti ipari cég és iparos család történetéröl is. A gyártólétesítmények épülettípusának történeti fejlődése területén azonban jó néhány iparágban még nem állnak rendelkezésre alapvető tudományos kutatási eredmények. Kivételt képeznek ez alól a budapesti történeti sörfőzdék és malátázók. Ezeknek az épületeknek a szisztematikus kutatása rengeteg hasznos ismerettel szolgál, hiszen a sörfőzőipar volt az egyik első iparág, mely a kézmüves előállításról átállt az ipari gyártásra. A nagy sörfőzdéket tekinthetjük az első olyan gyártólétesítményeknek, amelyeket valóban ipari épületnek nevezhetünk. Feltételezhető továbbá, hogy a korabeli szakemberek által tervezési elvként központba helye-

\footnotetext{
${ }^{1}$ A kiállítás tudományos szakértője, e publikáció szerzője. A kiállítás kurátora Hidvégi Violetta főlevéltáros, főtanácsos. Budapest Főváros Levéltára, 1139 Budapest, Teve utca 3-5. Tel.: (+36-1) 298-7542. E-mail: hidvegiv@bparchiv.hu
} 
zett funkcionális megközelítés, később más iparágak gyárépületeinek építészeti kialakítására is befolyást gyakorolt. ${ }^{2}$ Ily módon a sörfözde a gyár prototípusának is tekinthető. A Budapest Főváros Levéltára (a továbbiakban BFL) ${ }^{3}$ által rendezett kiállítás a nagyközönséghez kívánja közelebb hozni a budapesti történeti ipari építészet fejlődésének mérföldköveit.

A kiállítás kulcstémája a belvárosi sörfözdék fejlödése Pesten 1815-től egészen az ipari nagysörfőzdék 1870-es években kezdődő kialakulásáig. A korabeli sörfőzésben közreműködő személyiségek bemutatásával vázlatosan a társadalmi fejlődés és a város ipari építészeti fejlödésének kölcsönhatásai is nyomon követhetök. Az igényes kiállítási anyag a korszak számos kulturális szempontját górcső alá veszi. Teszi ezt a múlt őszinte ábrázolásával, így a látogatók számos váratlan szemponttal is szembe találkoznak majd. Így többek között megismerhetik az ágazati létesítmények tömegés arányviszonyainak változását is. A kiállítással párhuzamosan egy vándorkiállítás keretében bemutatásra kerül a németországi heidelbergi sörfözés története is. A két kiállítás egymást kiegészítve ábrázolja a két város azonos iparága építészeti fejlődésének hasonlóságait és különbözőségeit.

\section{A KIÁLLÍTÁS ELŐKÉSZÜLETEI ÉS MEGVALÓSÍTÁSA}

A kiállítás készítői a levéltárban őrzött gazdag irat- és tervanyagból válogattak. Ez a dokumentumok nagy száma miatt szigorú elvek alapján történt. A tervek és objektumok kiválasztása során nem volt könnyű dolguk a szervezőknek (kurátor: Hidvégi Violetta, tudományos tanácsadó: Dr. Martin Pilsitz). A szándék azonban világosan visszatükröződik: a középpontban az építészeti fejlődés lényegi momentumainak bemutatása állt. Az eredeti tervrajzokból történő válogatás során több változat is készült, melyeket ismételt felülvizsgálatnak vetettek alá. A végleges döntést a rendelkezésre álló információhordozók hatalmas száma nehezítette, ami Budapest Főváros Levéltára tervtárának gazdagságát jelzi. A kiállítás sikeréhez és szakmai színvonalához a levéltár számos munkatársa járult hozzá.

A kiállítás Budapest Főváros Levéltára első emeletén került megrendezésre. Az itt található üvegfalnak köszönhetően a kiállítótér vizuális kapcsolatot is biztosított az épület földszintjén a heidelbergi sörfőzést bemutató kiállítással, hiszen a két rendezvény egyidejüleg tartott nyitva. A kiállító helyiségben üveggel védett vitrinek és reprezentációs egységek domináltak, amelyek egyben térelválasztó szerepet is betöltöttek. A tervdokumentációk és kiállítási tárgyak a könnyebb megértés érdekében túlnyomórészt kronológiai sorrendben helyezkedtek el, és csak olyan esetekben kerültek tematikai kapcsolatban bemutatásra, amikor az összefüggés úgy kívánta. A rövid szöveges információs táblák, a korabeli tervrajzok és az egyéb kiállítási

\footnotetext{
${ }^{2}$ Martin Pilsitz: A korai ipari építészet mint a modern előfutára. Épités - Épitészettudomány 44 (2016) 3-4. $227-245$.

${ }^{3} 1139$ Budapest, Teve utca 3-5.
} 
tárgyak esztétikai kifejező erejének kombinációja a látogatót megfelelően inspirálta. A falakon látható történeti képanyag nemcsak tovább gazdagította a kiállítást, hanem a látogatókat mintegy önmagától vezette tovább a soron következő témakörhöz. További kreatív elemként említendő meg a kiállított objektumokat középpontba helyező megvilágítási koncepció. A tervdokumentációk így tükröződésmentesen és teljes terjedelmükben kapnak megvilágítást, ami a szövegek könnyü olvashatóságát is biztosította. A fogyatékossággal élők, így a kerekesszékkel közlekedők is, a kiállítótermet lifttel közelíthették meg.

\section{A KIÁLLÍTÁS ÁTTEKINTÉSE}

A látogatókat a török kiüzését követően (1686), a bajor származású sörfőző Proberger Jakab által üzemeltetett „Pest város serfőző házával” kapcsolatos leírások vezetik be a kiállítás témájába. Proberger Jakab 1711-ben bekövetkezett halála után a serföző házat Pest városa vásárolta meg, majd 3-3 évre a legtöbbet kínáló céhtagnak adta haszonbérletbe. Ez a rendszer egészen 1815-ig marad fenn. Építészeti és régészeti szempontból jelentős szerepet kapott a Duna és a városi serfőző ház között létesített 250 méter hosszú csatorna is, melynek tervrajzát a kiállítás anyaga szintén tartalmazza.

Ezt követi az 1815-ben megnyitott Mayerffy Serfözde építésének bemutatása, amely a mai V. kerületben, a Garibaldi utca 2-4. sz. alatt müködött. A serfözde építési munkáit Zitterbarth János (1776-1824) építőmester vezette. Az U alakú épületkomplexum udvarának megközelítése két kapun keresztül történt. Az udvart középen az üzem saját malmának négyszögletes épülete zárta le. Az épület egyesítette az ipari és a lakófunkciót. A földszinten az egymástól világosan elválasztott gyártó és értékesítési zónák találhatók. A gyártó zóna adott helyet a sör- és pálinkafözdének, az ecetfőző üzemnek. Az utcai oldalon elhelyezkedő értékesítési zóna a sörkimérést és az itt gyártott termékek eladóterét foglalta magába. A főtraktus felső szintjén helyezkedett el a lakóterület, bár a hátsó oldalszárny már a gyártási zónához tartozott. Az alaprajzi kialakításról világosan leolvashatók a sörgyártás folyamatai: az árparaktár, az őrlőmalom, a malátázó és a főzőház. Különösen érdekes ezzel kapcsolatban, hogy az új Mayerffy serfőző ház 1793-ból származó előzetes tervei is kiállításra kerülnek (1-3. ábra). A két elképzelés összevetése kiváló lehetőséget kínál a korábban tervezett változat és a végül megvalósított épületegyüttes közvetlen összehasonlítására.

A Mayerffy-serfözdét követi a vele közel egyidejüleg létesített Petz-serfözde bemutatása (1815, a mai IX. kerületben, a Ráday és a Kinizsi utca sarkán állt). ${ }^{4}$ A két épület hasonló koncepciójú, a Petz-serfőzde mégis jóval kisebb méreteiben, és építészete is visszafogottabb. Az időben elörehaladva a Mayerffy- és a Petz-serfőzde utáni időszakban létesítették az ún. Spiegel- (később Tüköry-)serfözdét, mely a mai

\footnotetext{
${ }^{4}$ Martin Pilsitz: 1805-1840 közötti pest-budai belvárosi sörfőzdék - a funkcionális célépítészet kezdetei. Historia Scientiarum 11 (2013) 1. 28-36.
} 


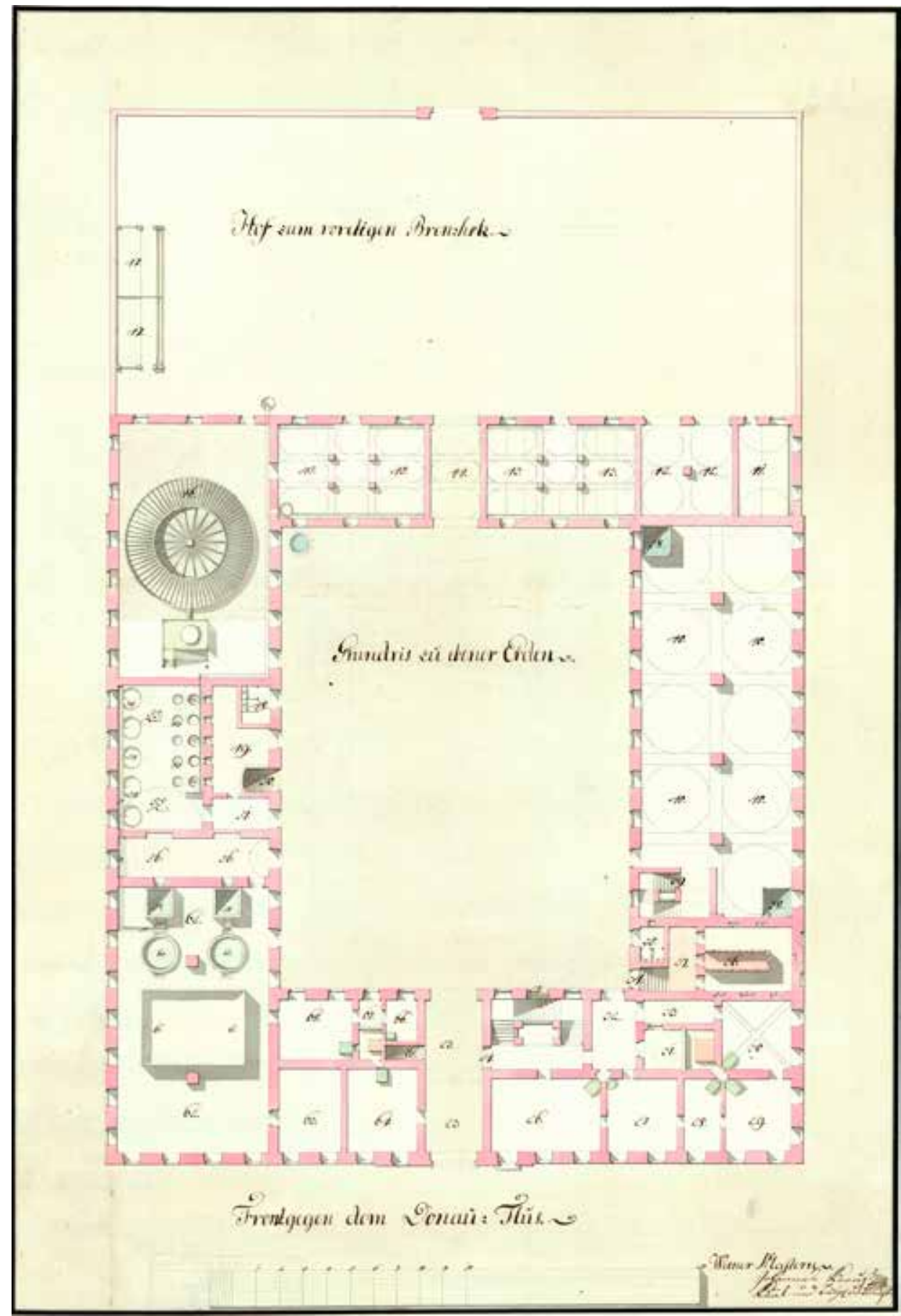

1. ábra. Pest város megvalósulatlan serfőzdéje. Földszinti alaprajz. Krauß János. 1793 (Forrás: BFL XV.17.b.314 78/b) 


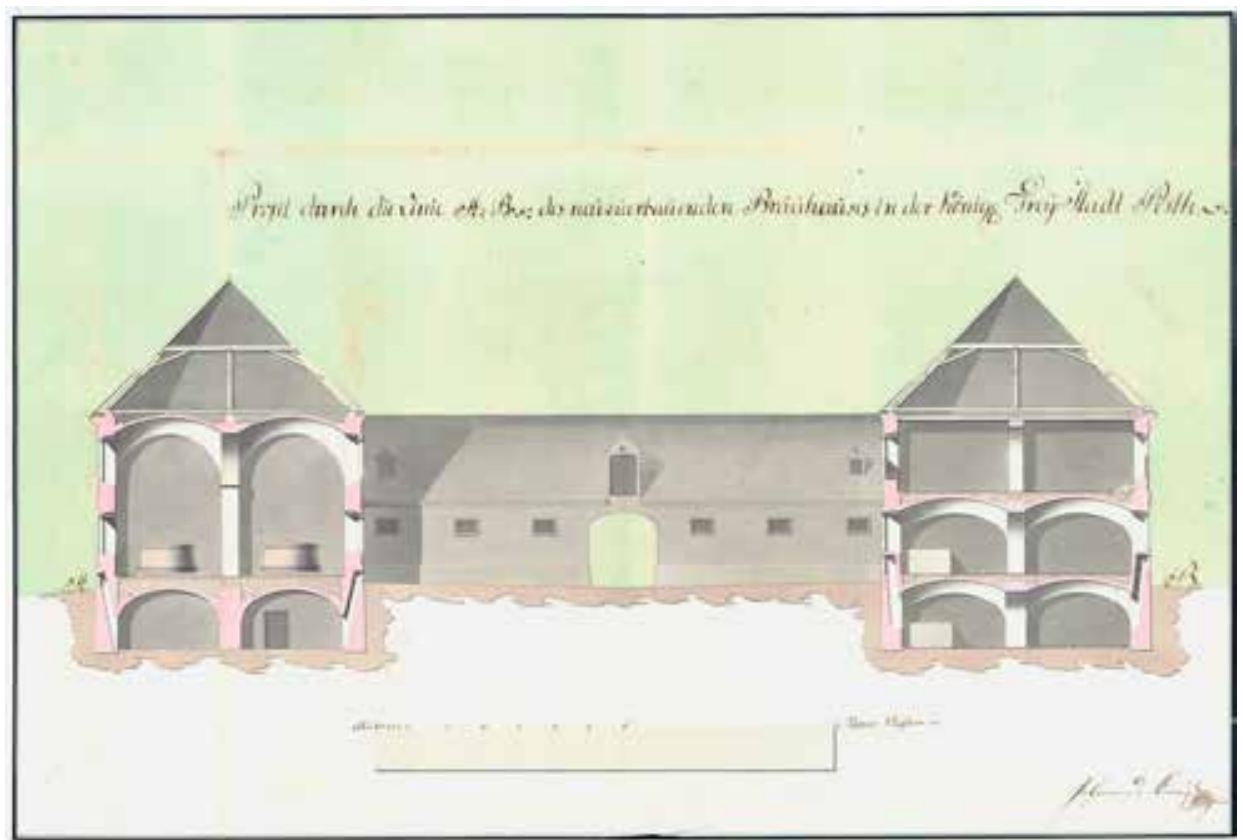

2. ábra. Pest város megvalósulatlan serfőzdéje. Metszet. Krauß János. 1793 (Forrás: BFL XV.17.b.314 78/d)

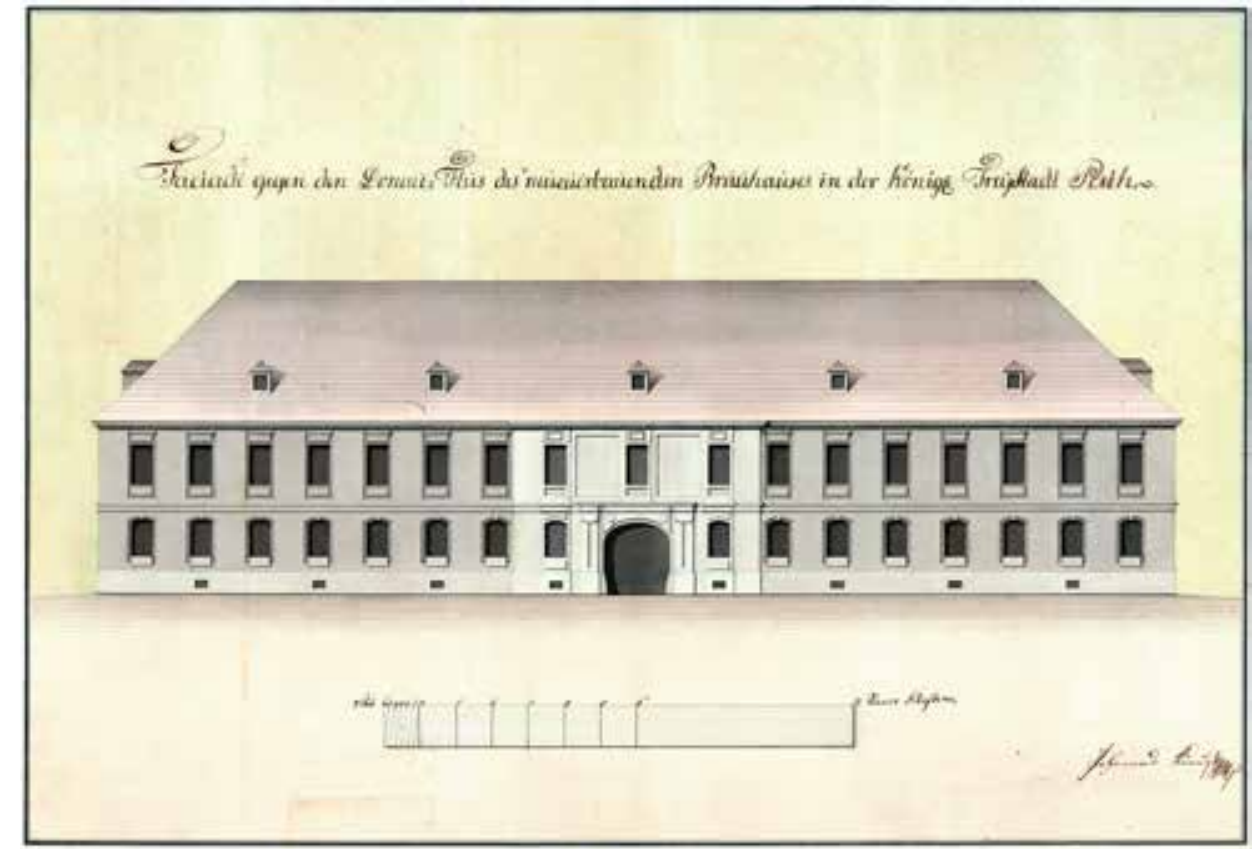

3. ábra. Pest város megvalósulatlan serfözdéje. Homlokzat. Krauß János. 1793 (Forrás: BFL XV.17.b.314 78/e) 
XIII. kerületben, a Szent István körút - Hollán Ernő - Katona József és a Pannónia utca által határolt területen helyezkedett el. A Spiegel-Tüköry József által 1832-ben alapított sörfőzdét Pollack Mihály tervezte. A középépülettel és két szárnnyal tervezett épületben malom is müködött.

A budapesti sörfözési technológia fejlődésében fordulópontot jelentett Schmidt Péter Üllői út 73-75. sz. alatt létesített serfőzdéje. A pesti származású ecet- és pálinkafőző mester a müncheni serfőző céhben szabadult mesterként, innen hozta magával a bajor alsóerjesztésủ sörfőzés módszerét, amelynek meghonosítója lett Pest-Budán (1845). Ez a technológia a sör ízbeli érlelése érdekében a legutolsó gyártási szakaszban több hónapon keresztül alacsony hömérsékletet és egyenletes légnedvességen történő raktározást igényelt. A kívánt klímaviszonyok érdekében raktárpince építése vált szükségessé, amely jelentős időbeli és anyagi ráfordítást jelentett a vállalkozónak. Schmidt ezért a raktározás gyártási szakaszát az Üllöi úti üzemtelepről a kb. 8 kilométerre fekvő kőbányai pincerendszerbe helyezte át. A kőbányai mészkövet elönyös tulajdonságai - könnyen faraghatósága - miatt már a pesti városfal építéséhez is hasznosították, de az itt bányászott kövekből emelték a XVIII. század elején a mai Központi Városháza épületét, az egykori Károlykaszárnyát is. A fejtés során széles és mély aknákat vágtak, amelyeket felül termőföld borított, így jöttek létre előbb a bor, később a sör tárolására szolgáló pincék. A sörgyártás speciális tulajdonságokkal rendelkező helyszínre történő kiszervezésével egy átmeneti korszak vette kezdetét, melynek során a gyártás egyes szakaszai különböző földrajzi helyekre kerültek. Ezt később a teljes sörfőző üzemeknek a város peremére történő elvándorlása követte.

A kiállítás további kulcsfontosságú része a kőbányai pincerendszer bemutatása. Az itt kialakított föld alatti raktárhelyiségek funkciójukat, különleges építészeti kialakításukat és hatalmas kiterjedésüket tekintve is jelentős szerepet töltenek be Budapest technikai épületei körében. A föld alatti létesítményt az évszázadok során szélesen elágazó alagútrendszerré fejlesztették tovább. A 19. század közepén malátázókat, raktár- és erjesztő pincéket, sőt sörfőzdék részegységeit is elhelyeztek a pincejáratokban. Pest város Szépítő Bizottmánya 1850-ben tárgyalta a Kőbányai Serfőző Társaság serfőző házának építési terveit, amelyeket Zofahl Lőrinc építőmester készített. Az építési munkálatok nagy földmunkával jártak, ez a kor technikai felszerelésével jelentős időráfordítást igényelt. Ennek a sörfőzdének az építészeti innovációs jellege a geológiai adottságok és a topográfiai sajátosságok integrálásában rejlik, ami nem utolsósorban kisebb építési telek megvásárlását is lehetővé tette. A meglévő pincejáratokat már korábban is használták erjesztö- és raktárpincének, Zofahl azonban felismerte a természetes térben rejlö kitünő lehetőségeket. A külső tér és a hegy belső terének találkozása között gyártóhelyiségek rendszerét alakította ki, amelyek alaprajza és belmagassága a funkciótól függően egyedileg került kialakításra. A munka során a helyiségek elsődlegesen nem falazott falakkal lehatárolva keletkeztek, hanem a természetes kőzet elhordásával. Ezzel a „reciprok” téralakítási módszerrel a természetes kőrétegben akár 7,5 méterig terjedő belmagasságú, csarnokszerü terek jöttek létre, amelyek felső lezárását a masszív kőboltozatok alkotják. Ez az építészeti 


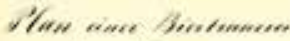

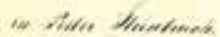

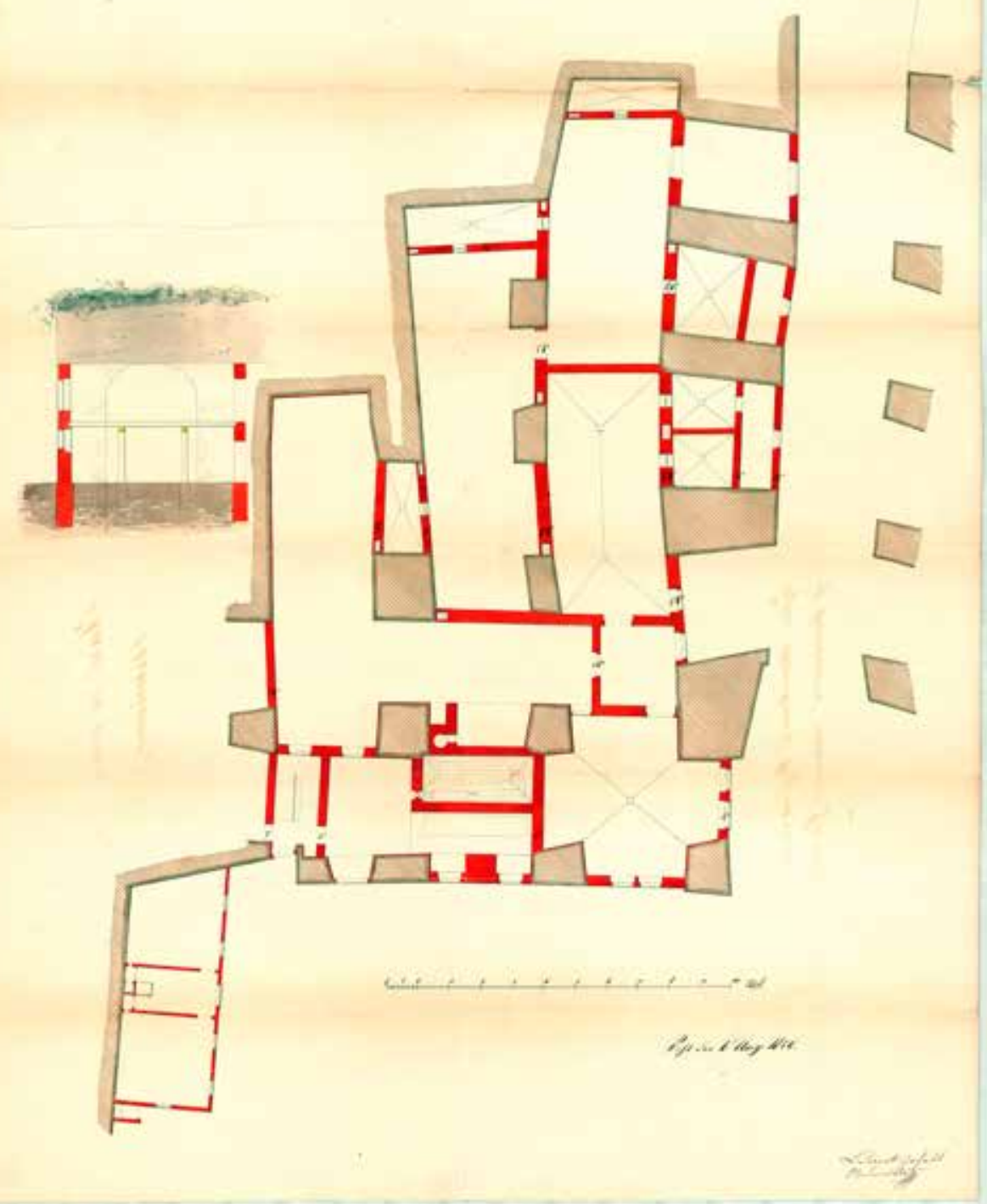

4. ábra. Kőbányai serfőzde pince. Alaprajz. Zofahl Lőrinc. 1850

(Forrás: BFL XV.17.b.314 21) 
kifejeződési forma a technikai és gazdasági megfontolásokon túl a megbízhatóság és a fenntarthatóság érzetét sugározza. A kiépített pince alapterülete $450 \mathrm{~m}^{2}$-t tett ki. A malátázó szérű föld alatti elhelyezésének előnye volt, hogy kevésbé volt kitéve a külső hőmérsékletingadozásnak és közvetlen napsugárzásnak. A létesítménybe számos technikai berendezést is integráltak, pl. kéményeket, szellőzőaknákat, padló vízösszefolyókat és főzőberendezéseket. Az átszellőztetéshez légaknákat építettek be, a szénsavtartalmú elhasznált levegőt a mennyezet magasságában beépített nyílásokon vagy kéményeken keresztül vezették ki a szabadba. A raktárpince a pincerendszer hátsó és kiépítetlen részében helyezkedett el, melyet több ajtón keresztül közelítettek meg. A körülvevő mészkő és a feltöltött talaj hőszigetelő tulajdonsága, valamint a természetesen magas légnedvesség pótlólagos energia bejuttatása nélkül is érést támogató belső klímát eredményezett. A pincerendszer aktív kiépítéséhez égetett téglát használtak (falvastagsága: 0,52 , illetve $0,36 \mathrm{~m}$ ), mely sima felületével kontrasztot teremtett a pince természetes kö felületével. A köztes födémeket fagerenda-szerkezettel készítették, mivel a raktározandó nyersanyag: árpa és komló nem túlságosan súlyos. A gyártási területtől függően kialakított ablakok beengedték a nappali fényt, és az igény szerinti légcserét is lehetővé tették (4. és 5. ábra).

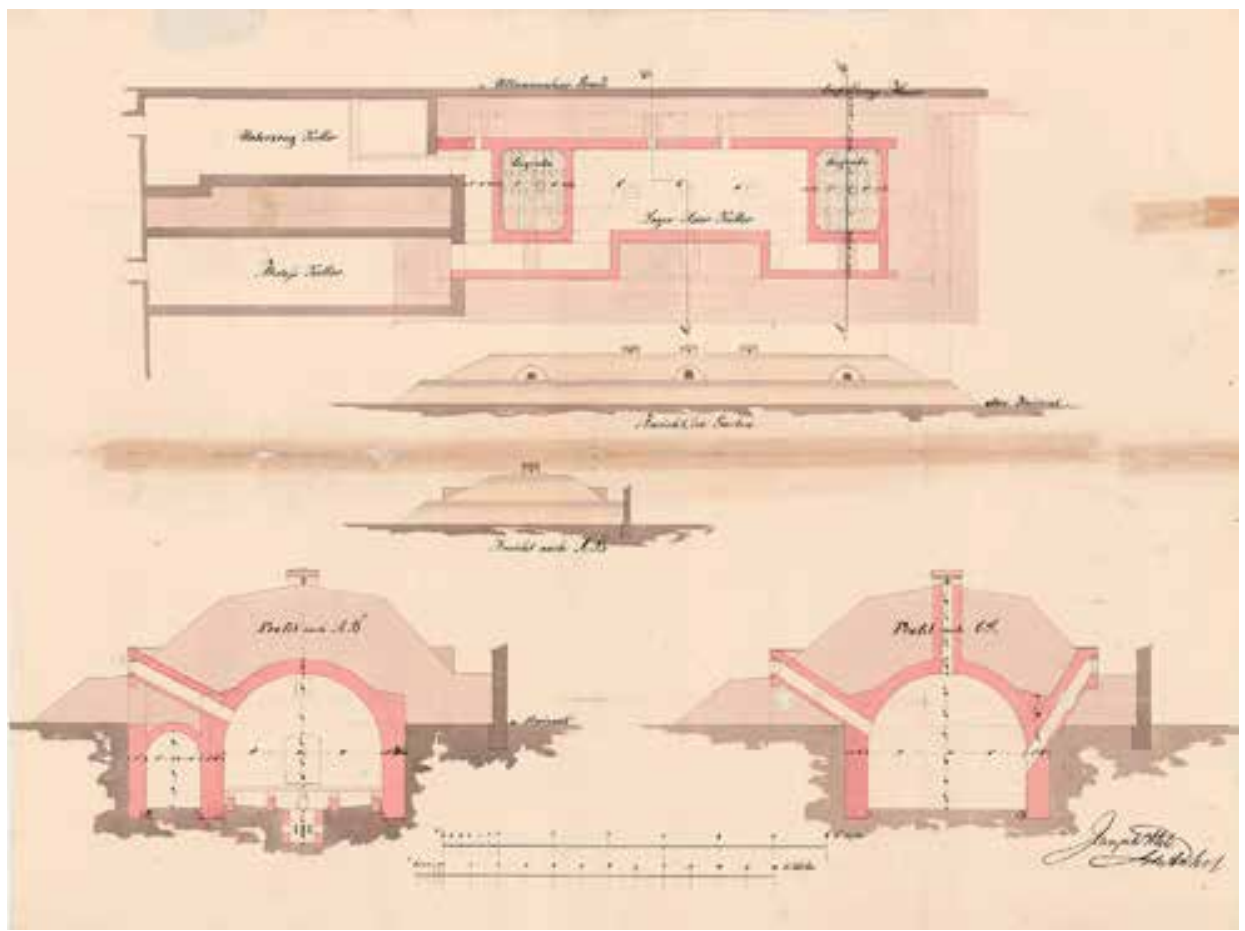

5. ábra. Új serpince. Alaprajz. Metszet. Nézet. Hild József. 1844 (Forrás: BFL XV.17.b.311 10667) 
A kiállitás további részében a történelmi tervanyagok segítségével különböző müszaki célú épületek, pl. aszalók és korabeli hütőházak müködését ismerhetik meg a látogatók. A Tüköry-sörcsarnok példáján keresztül olyan épülettípus is megjelenik, amely ebben a formában Magyarországon nem maradt fenn. A 19. század végén a sörcsarnokok a vendéglátóhelyek önálló formáját jelentették, amelyeket legtöbbször sörfözdékhez kapcsoltan, a forgalom helyszínen történő növelése érdekében létesítettek. A sörcsarnokokhoz gyakran tartozott parkosított kert, és nem egyszer igazi polgári kirándulóhelyként is szolgáltak.

A Budapest Főváros Levéltárában rendezett kiállítás széles körü érdeklődésre tarthat számot, amely minőségi anyaggal várja a Budapest gazdag ipari múltja iránt érdeklődőket. A látogatók széles körü áttekintést szerezhetnek a budapesti építészettörténet e saját korában igen fejlett, mégis aránylag kis figyelemben részesített szeletéröl. A kiállítás szervezői nem szenzációs darabokat vagy döbbenetes kivételeket kívántak kiemelni, hanem a téma átfogó és informatív bemutatására törekedtek. A rendkívül gazdag és messzemenően publikálatlan történeti tervanyagra támaszkodva tárták fel a helyi sörfőzde-építészet látványos fejlődését. Az építészeti és társadalmi fejlődés kölcsönhatásainak kiemelése és bemutatása új szemszögből is rávilágít Budapest történeti ipari építészetének jelentőségére. A nagy érdeklődésre való tekintettel remélhető, hogy a témakörben újabb kiállítások is következnek.

\title{
EVOLUTION FROM THE BREW HOUSES OF PEST TO THE INDUSTRIAL BREWERIES
}

\author{
EXHIBITION ON THE HISTORY OF THE INDUSTRIAL ARCHITECTURE \\ BUDAPEST CITY ARCHIVES \\ (09. June $2017-31$. Oct 2017)
}

\begin{abstract}
Summary
The industrial and technical history of the city of Budapest is largely researched and the results are documented in the comprehensive literature. The same applies to the history of individual companies and industry families. The historical development of the production facilities as a type of building are for the most industrial sectors not yet finally scientificly studied. An exception is the area of brewing and malting. Why these buildings were the subject of first systematical investigations is quite logical. The brewing industry was the first branch, in them craft methods changed to industrial production methods. This is also the explanation for why we can consider the production plants of the breweries as the first industrial building. The exhibition in the rooms of the Budapest City Archives is dedicated to the architectural development of the inner-city brewing houses in Pest (1815) up to the beginnings of the large industrial breweries in Budapest-Köbánya (1870). Furthermore, the explanation provides a variety of information to persons of the branch, which provides for interaction between social development and industrial history of the city. These make the presentation to a socially and culturally oriented high level exhibition.
\end{abstract}

Keywords: Dreher, József Hild, historical breweries in Budapest, János Krauß, Mayerffy, Proberger, Tüköry, Lőrinc Zofahl 


\title{
VON DEN PESTER BRAUHÄUSERN ZU DEN INDUSTRIELLEN GROSSBRAUEREIEN
}

\author{
AUSSTELLUNG ZUR BAUGESCHICHTE DER INDUSTRIEARCHITEKTUR \\ HAUPTSTÄDTISCHES ARCHIV BUDAPEST
}

$(09.06 .2017-31.10 .2017)$

\section{Zusammenfassung}

Die Industrie- und Technikgeschichte der Stadt Budapest ist weitgehend aufgearbeitet und die Ergebnisse in einer umfassenden Literatur dokumentiert. Das gleiche gilt bezüglich der Geschichte einzelner Firmen und Industriefamilien. Was allerdings die historische Entwicklung der Produktionsstätten als Gebäudetyp betrifft, liegen für die meisten Industriezweige noch keine endgültigen wissenschaftlichen Untersuchungen vor. Eine Ausnahme bilden die Brauereien und Mälzereien. Das gerade diese Gebäude als erste systematisch untersucht wurden, ist durchaus sinnvoll. Das Brauwesen war der erste Industriezweig, in dem von handwerklicher auf industrielle Produktionsweise umgestellt wurde. Damit wurden die Brauereien auch die ersten Produktionsstätten, die als Industriegebäude bezeichnet werden können. Eine Ausstellung in den Räumen des Hauptstädtischen Archivs Budapest widmet sich nun der architektonischen Entwicklung der Innerstädtischen Brauhäuser in Pest (1815) bis zu den Anfängen der Industriellen Großbrauereien in Budapest-Kőbánya (1870). Darüber hinaus wird eine Vielzahl von Informationen zu den handelnden Personen vermittelt, wodurch die Wechselwirkung zwischen gesellschaftlicher Entwicklung und industrieller Baugeschichte der Stadt skizzenhaft aufgezeigt wird. Insgesamt wird die Präsentation dadurch zu einer kulturell ausgerichteten Ausstellung auf hohem Niveau.

Schlüsselwörter: Dreher, Hild József, Historische Brauereien in Budapest, János Krauß, Mayerffy, Proberger, Tüköry, Lörinc Zofahl 